\title{
Upaya Pengurangan Human Error Pada Kecelakaan Kerja Dengan Metode Sherpa Dan Jsa Di Perum Perhutani Kbm - Industri Kayu Gresik
}

\author{
Abdi Rahayu*, Heri Mujayin Kholik, Dian Palupi Restuputri \\ Jurusan Teknik Industri, Universitas Muhammadiyah Malang \\ Jl. Raya Tlogomas 246 Malang 65144 Jawa Timur \\ *Surel: abdirahayu12@gmail.com
}

\begin{abstract}
Perum Perhutani KBM-IK (Kesatuan Bisnis Mandiri Industri Kayu) Gresik is a unit of the organization under the Office of Perum Perhutani Unit II East Java, which is responsible for the implementation of business management in the field of Industi Wood. In the production process, Perum Perhutani has used the modern machining tools. However, due to the negligence of the operator / worker, often causing work accident. Like do not use personal protective equipment, it is often underestimated by the operator. The method used is SHERPA to identify the source of danger while JSA used to provide solutions to the problems faced in companies. Research and calculation of risk score can be known the value of the biggest error lies in the activities taking pieces of the board after the cut using a band saw machine, cutting boards using a machine band resaw and cutting wood with a cross cut machine. The suggested solution is to further improve supervision in each process, conducting training K3 conducted by the management company, give firm sanction for operators who do not wear APD and design tools such as limiting engine band resaw and handle holder on the machine cross cut.
\end{abstract}

Key Word: Human Error, Work Accident, SHERPA, risk score and JSA.

\begin{abstract}
Abstrak
Perum Perhutani KBM-IK (Kesatuan Bisnis Mandiri Industri Kayu) Gresik adalah satuan organisasi dibawah Kantor Perum Perhutani Unit II Jawa Timur yang bertanggung jawab atas penyelenggaraan pengelolaan usaha di bidang Industi Kayu. Perum Perhutani telah menggunakan alat permesinan yang modern untuk proses produksi. Namun karena kelalaian operator/pekerja, sering menyebabkan timbulnya kecelakaan kerja. Seperti tidak menggunakannya alat pelindung diri sering dianggap remeh oleh operator. Metode yang digunakan yaitu SHERPA untuk mengidentifikasi sumber bahaya sedangkan JSA digunakan untuk memberikan solusi atas masalah yang dihadapi perusahaan. Perhitungan skor resiko diketahui nilai error terbesar terletak pada kegiatan mengambil potongan papan setelah dipotong menggunakan mesin band saw, memotong papan menggunakan mesin band resaw dan memotong kayu dengan mesin cros scut. Solusi yang diberikan adalah dengan meningkatkan pengawasan pada setiap proses, melakukan pelatihan K3, memberi sangsi tegas bagi operator yang tidak memakai APD dan membuat desain alat bantu berupa pembatas mesin band resaw dan handle pemegang pada mesin cros scut.
\end{abstract}

Kata Kunci: Human Error, Kecelakaan Kerja, SHERPA, skor resiko dan JSA.

\section{Pendahuluan}

Manusia dalam melakukan pekerjaannya cenderung mengalami error (kesalahan). Menurut Wignjosoebroto (2000) [1] dari berbagai hal yang menyangkut permasalahan manusia dalam berinteraksi dengan produk, mesin ataupun fasilitas kerja lain yang dioperasikannya, manusia seringkali dipandang sebagai sumber 
penyebab segala kesalahan, ketidakberesan maupun kecelakaan kerja (human error). Buchari,dkk (2013) [2] menganalisa human error pada kecelakaan kerja yang terjadi di PT (XYZ) pada bagian Wet Area, Talcum Area dan Packing Area. Hasil penelitiannya menyatakan bahwa error terbesar merupakan operator tidak menggunakan APD (Alat Pelindung Diri).

Proses produksi Perum Perhutani menggunakan alat permesinan yang bervariasi serta membutuhkan konsentrasi. Mulai dari produk masuk hingga pengemasan dilakukan oleh mesin. Namun karena kelalaian operator/pekerja, sering menyebabkan timbulnya kecelakaan kerja. Seperti tidak menggunakan alat pelindung diri yang sering dianggap remeh oleh operator. Kecelakaan yang terjadi antara lain kaki tertimpa balok, jari terpotong, dan tangan tergores mesin.

Makalah ini menguraikan suatu analisis yang digunakan untuk mengurangi terjadinya human error (kesalahan operator) pada saat melakukan pekerjaannya. Metode analisis yang digunakan adalah SHERPA (Systematic Human Error Reduction Production Technic) digunakan untuk menganalisis mode error serta mengidentifikasi sumber penyebab kecelakaan dan JSA (Job Safety Analysis) digunakan untuk memberikan solusi pada error yang terjadi.

Tujuan makalah dengan metode SHERPA dan JSA ini adalah untuk mengetahui penyebab kecelakaan berdasarkan perhitungan Skor Resiko pada Analisis Ordinal Probabilitas dan memberikan solusi perbaikan terhadap error tersebut. Makalah ini hanya mancakup pada departemen produksi flooring.

\section{Metode Penelitian}

Metode yang digunakan untuk menyelesaikan masalah pada makalah ini dengan metode SHERPA (Systematic Human Error Reduction Production Technic) dan JSA (Job Safety Analysis). Salmon (2003) [3] menjelaskan bahwa SHERPA merupakan salah satu metode untuk menganalisa terjadinya human error dengan menggunakan input hirarki task level dasar dan Hutama (2015) [4] menguraikan bahwa JSA merupakan salah satu usaha dalam menganalisa tugas prosedur yang ada di suatu industri.

Makalah ini disusun melalui beberapa tahap yaitu studi lapangan dan study pustaka, pengumpulan data, membagi kegiatan ke dalam kelompok kerja Hierarchycal Task Analysis (HTA), pengolahan data dengan metode SHERPA. Metode SHERPA yang pertama mengidentifikasi error berdasarkan tabel mode error. Tahap berikutnya adalah menentukan konsekuensi dari human error yang terjadi, dan tahap terakhir adalah analisis ordinal probabilitas dengan melihat tabel ordinal probabilitas [5, 6]. Tabel ini menunjukkan tingkat kekritisan dari konsekuensi human error yang terjadi.

Tahap menghitung Skor Resiko, dalam tahap ini digunakan untuk menentukan kegiatan yang dianalisis menggunakan metode JSA dengan rumus [7] :

\section{Skor Resiko=Level Keparahan $\times$ Kasus Serupa}

Pengolahan data menggunakan metode JSA dengan langkah menilai tingkat bahaya dan resiko dan mengendalikan bahaya dengan cara membuat form JSA.

\section{Hasil dan Pembahasan}

Untuk dapat membuat bagan HTA, terlebih dahulu harus mengetahui alur proses produksi flooring. 


\subsection{Proses Produksi Flooring}

Gambar 1 merupakan bagan alur proses produksi flooring, ada 9 proses utama yaitu penggergajian balok kayu, pemotongan lebar kayu, pemotongan panjang kayu, pembuatan $\mathrm{T} \& \mathrm{G}$, pembuatan double end, penghalusan, pengeringan, inspeksi dan packaging.

\subsection{Hierarchycal Task Analysis (HTA)}

Tabel 1 Hierarchecal Task Analysis Produksi flooring

\begin{tabular}{|c|c|c|}
\hline Kegiatan & $\begin{array}{l}\text { No. } \\
\text { Task }\end{array}$ & Kegiatan \\
\hline \multirow{6}{*}{$\begin{array}{l}\text { Penggergajian } \\
\text { Kayu }\end{array}$} & 1.1 & Menempatkan kayu pada loadingdect \\
\hline & 1.2 .1 & Meletakkan balok kayu pada lintasan gelinding \\
\hline & 1.2 .2 & Menggelindingkan balok kayu pada mesin mendekati mesin \\
\hline & 1.3 .1 & Mengangkat balok kayu pada handle mesin \\
\hline & 1.3 .2 & Mengoperasikan carriage \\
\hline & 1.4 & $\begin{array}{l}\text { Mengambil potongan papan setelah dipotong oleh mesin } \\
\text { bandsaw }\end{array}$ \\
\hline \multirow{5}{*}{$\begin{array}{l}\text { Pemotongan Lebar } \\
\text { Kayu }\end{array}$} & 2.1 & Mengangkut papan kayu menuju conveyor \\
\hline & 2.2 & Membersihkan permukaan papan kayu \\
\hline & 2.3 .1 & Membersihkan mata gergaji dari serbuk kayu \\
\hline & 2.3 .2 & Mengasah mata gergaji \\
\hline & 2.4 & Memotong papan menggunakan mesin band resaw \\
\hline \multirow{5}{*}{$\begin{array}{l}\text { Pemotongan Panjang } \\
\text { Kayu }\end{array}$} & 3.1 .1 & Mengambil kayu dari tumpukan \\
\hline & 3.1 .2 & Mengangkat kayu dari tumpukan \\
\hline & 3.2 .1 & Membersihkan mata gergaji dari serbuk kayu \\
\hline & 3.2 .2 & Mengasah mata gergaji \\
\hline & 3.3 & Meletakkan kayu pada handle mesin crosscut \\
\hline \multirow{3}{*}{ Pembuatan T\&G } & 4.1 .1 & Mengambil dan mengangkat kayu dari tumpukan (forklift) \\
\hline & 4.2 .1 & Mengambil kayu dari tumpukan (tangan) \\
\hline & 4.3 & Mensetting spesifikasi ukuran pembuatan T\&G \\
\hline \multirow[t]{2}{*}{ Pembuatan DoubleEnd } & 5.1 .1 & Mengambil kayu dari tumpukan (tangan) \\
\hline & 5.2 & Mensetting ukuran pembuatan doubleend \\
\hline \multirow{3}{*}{ Penghalusan } & 6.1 & Mengambil kayu dari tumpukan \\
\hline & 6.2 & Mengangkat kayu mendekati mesin penghalus \\
\hline & 6.3 & Mensetting mesin \\
\hline \multirow{5}{*}{ Pengeringan } & 7.1 .1 & Mengambil kayu dari tumpukan (forklift) \\
\hline & 7.1 .2 & Menyusun kayu pada tumpukan \\
\hline & 7.2 .1 & Membersihkan mesin kilndry \\
\hline & 7.2 .2 & Mensetting suhu mesin kilndry \\
\hline & 7.3 .1 & Mencatat suhu mesin kilndry \\
\hline \multirow{6}{*}{ Inspeksi } & 8.1 & Mengecek ukuran potongan papan pada mesin bandsaw \\
\hline & 8.2 & Mengecek ukuran papan pada mesin bandresaw \\
\hline & 8.3 & Mengecek ukuran T\&G dan doubleend \\
\hline & 8.4 & Mengecek kayu pada mesin sanding \\
\hline & 8.5 & Mengecek kayu pada mesin kilndry \\
\hline & 8.6 & Memastikan kerapian packaging \\
\hline \multirow{3}{*}{ Packaging } & 9.1 & Menyiapkan kardus pembungkus \\
\hline & 9.2 & Menyususun kayu \\
\hline & 9.3 & Mengikat kayu \\
\hline
\end{tabular}


Tabel 1 merupakan HTA dari proses produksi flooring. Data HTA yang dibuat mulai dari proses penggergajian balok kayu hingga proses packaging secara detail.

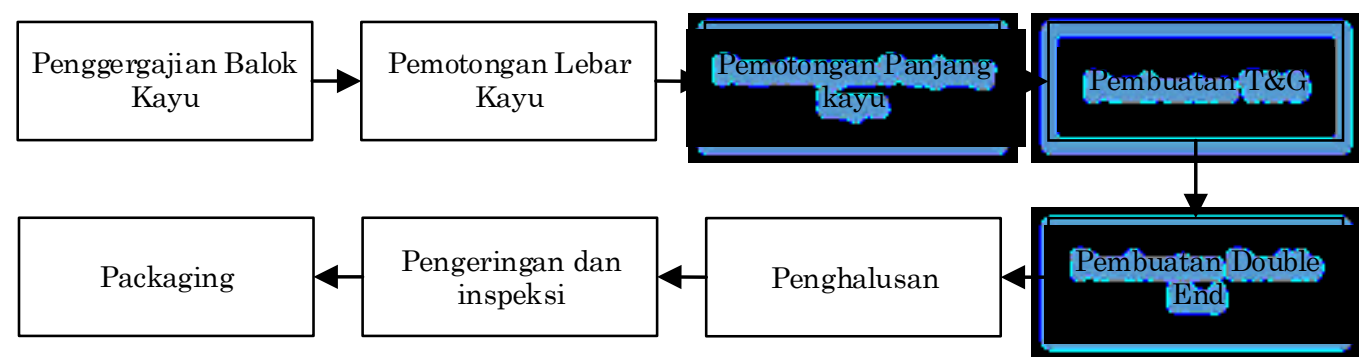

Gambar 1 Bagan Alur Proses Produksi flooring

\subsection{SHERPA}

Tabel 2 Pengerjaan dengan Metode SHERPA

\begin{tabular}{|c|c|c|c|c|c|c|c|}
\hline Kegiatan & $\begin{array}{l}\text { No. } \\
\text { Task }\end{array}$ & $\begin{array}{l}\text { Tabel } \\
\text { Mode } \\
\text { Error }\end{array}$ & Deskripsi Error & $\begin{array}{l}\text { Konsekuensi } \\
\text { Human Error }\end{array}$ & $\begin{array}{c}\text { Level } \\
\text { Keparahan }\end{array}$ & $\begin{array}{l}\text { Kasus } \\
\text { Serupa }\end{array}$ & $\begin{array}{l}\text { Skor } \\
\text { Resiko }\end{array}$ \\
\hline \multirow[t]{6}{*}{1} & 1.1 & $\mathrm{~A} 4$ & $\begin{array}{lr}\text { Operator } & \text { salah } \\
\text { menjatuhkan } & \text { balok } \\
\text { kayu } & \text { saat } \\
\text { memindahkan } & \text { balok } \\
\text { dari tumpukan } & \end{array}$ & $\begin{array}{l}\text { Balok } \\
\text { menjatuhi kaki } \\
\text { operator } \\
\text { pekerja }\end{array}$ & 5 & 2 & 10 \\
\hline & 1.2 .1 & A6 & $\begin{array}{lr}\text { Saat } & \text { operator } \\
\text { mengangkat } & \text { balok } \\
\text { kayu dari loadingdect } \\
\text { ke lintasan } & \text { gelinding } \\
\text { operator } & \text { tidak } \\
\text { memakai } & \text { sepatu } \\
\text { safety } & \end{array}$ & $\begin{array}{l}\text { Kaki tertimpa } \\
\text { balok kayu }\end{array}$ & 5 & 2 & 10 \\
\hline & 1.2 .2 & A7 & $\begin{array}{l}\text { Operator } \\
\text { menggelindingkan } \\
\text { balok kayu dengan } \\
\text { tangan kosong }\end{array}$ & $\begin{array}{l}\text { Tangan terjepit } \\
\text { balok kayu, } \\
\text { tangan tertusuk } \\
\text { bagian kayu } \\
\text { yang tajam }\end{array}$ & 3 & 1 & 3 \\
\hline & 1.3 .1 & A7 & 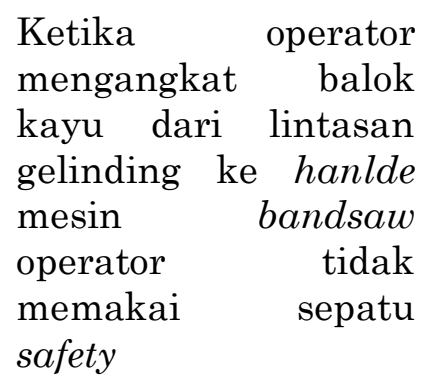 & $\begin{array}{l}\text { Kaki tertimpa } \\
\text { balok kayu, } \\
\text { tangan keseleo }\end{array}$ & 4 & 2 & 8 \\
\hline & 1.3 .2 & $\mathrm{R} 2$ & $\begin{array}{l}\text { Saat operator } \\
\text { mengoperasikan } \\
\text { carriage, ia tidak } \\
\text { melihat sekitar } \\
\text { lintasan carriage }\end{array}$ & $\begin{array}{l}\text { Kaki } \\
\text { terlindasan } \\
\text { carriage }\end{array}$ & 3 & - & - \\
\hline & 1.4 & A8 & Pekerja mengambil & tangan & 5 & 3 & 15 \\
\hline
\end{tabular}




\begin{tabular}{|c|c|c|c|c|c|c|c|}
\hline & & & $\begin{array}{l}\text { potongan papan tanpa } \\
\text { menggunakan APD } \\
\text { lengkap dan tanpa } \\
\text { ada pemisah antara } \\
\text { mesin dan pekerja }\end{array}$ & terpotong & & & \\
\hline \multirow[t]{5}{*}{2} & 2.1 & A3 & $\begin{array}{l}\text { Operator tidak } \\
\text { menggunakan sarung } \\
\text { tangan safety pada } \\
\text { saat memindahkan } \\
\text { papan dari conveyor }\end{array}$ & $\begin{array}{lr}\text { Jari } & \text { tangan } \\
\text { tertusuk } & \text { bagian } \\
\text { kayu } & \text { yang } \\
\text { tajam, } & \text { jari } \\
\text { tangan } & \text { terjepit } \\
\text { diantara } & \\
\text { conveyor } & \end{array}$ & 3 & 1 & 3 \\
\hline & 2.2 & A9 & $\begin{array}{l}\text { Operator kurang teliti } \\
\text { pada } \\
\text { membersihkan serbuk } \\
\text { kayu permukaan } \\
\text { papan dan tidak } \\
\text { memakai kacamata } \\
\text { safety }\end{array}$ & $\begin{array}{lr}\text { Serbuk } & \text { kayu } \\
\text { masuk } & \text { kedalam } \\
\text { mata dan } \\
\text { hidung }\end{array}$ & 1 & - & - \\
\hline & 2.3 .1 & $\mathrm{C} 1$ & $\begin{array}{l}\text { Operator ceroboh saat } \\
\text { membersihkan mata } \\
\text { gergaji }\end{array}$ & $\begin{array}{l}\text { Jari tergores } \\
\text { mata gergaji }\end{array}$ & 4 & 1 & 4 \\
\hline & 2.3 .2 & A8 & $\begin{array}{l}\text { Tidak memakai } \\
\text { sarung tangan safety }\end{array}$ & $\begin{array}{l}\text { Tangan } \\
\text { tertusuk mata } \\
\text { gergaji }\end{array}$ & 4 & - & - \\
\hline & 2.4 & A7 & $\begin{array}{lr}\text { Operator } & \text { tidak } \\
\text { memakai } & \text { APD } \\
\text { lengkap } & \text { saat } \\
\text { melakukan } & \\
\text { pemotongan } & \\
\text { menggunakan } & \text { mesin } \\
\text { bandresaw } & \end{array}$ & $\begin{array}{l}\text { Jari tangan } \\
\text { tergores, jari } \\
\text { tangan } \\
\text { terpotong }\end{array}$ & 5 & 4 & 20 \\
\hline \multirow[t]{5}{*}{3} & 3.1 .1 & A4 & $\begin{array}{l}\text { Operator mengambil } \\
\text { kayu dengan posisi } \\
\text { tubuh yang salah dan } \\
\text { tidak memakai } \\
\text { sarung tangan safety }\end{array}$ & $\begin{array}{l}\text { Tangan } \\
\text { tertusuk bagian } \\
\text { kayu tajam, } \\
\text { nyeri punggung }\end{array}$ & 3 & 1 & 3 \\
\hline & 3.1 .2 & A4 & $\begin{array}{l}\text { Operator terlalu } \\
\text { banyak mengangkut } \\
\text { kayu }\end{array}$ & $\begin{array}{l}\text { Kaki tertimpa } \\
\text { potongan kayu }\end{array}$ & 4 & 2 & 8 \\
\hline & 3.2 .1 & $\mathrm{C} 1$ & $\begin{array}{l}\text { Operator ceroboh saat } \\
\text { membersihkan mata } \\
\text { gergaji }\end{array}$ & $\begin{array}{l}\text { Jari tergores } \\
\text { mata gergaji }\end{array}$ & 3 & 1 & 3 \\
\hline & 3.2 .2 & A8 & $\begin{array}{l}\text { Tidak memakai } \\
\text { sarung tangan safety }\end{array}$ & $\begin{array}{l}\text { Tangan } \\
\text { tertusuk mata } \\
\text { gergaji }\end{array}$ & 4 & - & - \\
\hline & 3.3 & A7 & $\begin{array}{l}\text { Operator } \\
\text { memakai } \\
\text { lengkap } \\
\text { melakukan }\end{array}$ & $\begin{array}{l}\text { Jari tangan } \\
\text { terpotong } \\
\text { bahkan lengan } \\
\text { bisa terpotong }\end{array}$ & 5 & 3 & 15 \\
\hline
\end{tabular}




\begin{tabular}{|c|c|c|c|c|c|c|c|}
\hline & & & $\begin{array}{l}\text { pemotongan } \\
\text { menggunakan mesin } \\
\text { cross cut }\end{array}$ & & & & \\
\hline \multirow[t]{3}{*}{4} & 4.1 .1 & $\mathrm{~A} 6$ & $\begin{array}{lr}\text { Operator } & \text { tidak } \\
\text { berhati-hati } & \text { dalam } \\
\text { mengambil } & \text { di } \\
\text { tumpukan } & \end{array}$ & $\begin{array}{l}\text { Pekerja } \\
\text { tertimpa } \\
\text { tumpukan kayu }\end{array}$ & 2 & 2 & 4 \\
\hline & 4.2 .1 & A4 & $\begin{array}{l}\text { Operator mengambil } \\
\text { kayu dengan posisi } \\
\text { tubuh yang salah dan } \\
\text { tidak memakai } \\
\text { sarung tangan safety }\end{array}$ & $\begin{array}{l}\text { Tangan } \\
\text { tertusuk bagian } \\
\text { kayu tajam, } \\
\text { nyeri punggung }\end{array}$ & 3 & 1 & 3 \\
\hline & 4.3 & R3 & $\begin{array}{lr}\text { Operator } & \text { salah } \\
\text { mengatur ukuran } \\
\text { T\&G sesuai pesanan }\end{array}$ & $\begin{array}{l}\text { Produk } \quad \text { T\&G } \\
\text { rusak }\end{array}$ & 1 & - & - \\
\hline \multirow[t]{2}{*}{5} & 5.1 .1 & $\mathrm{~A} 4$ & $\begin{array}{l}\text { Operator mengambil } \\
\text { kayu dengan posisi } \\
\text { tubuh yang salah dan } \\
\text { tidak memakai } \\
\text { sarung tangan safety }\end{array}$ & $\begin{array}{l}\text { Dapat } \\
\text { menyebabkan } \\
\text { sakit punggung }\end{array}$ & 2 & - & - \\
\hline & 5.2 & R3 & $\begin{array}{lr}\text { Operator } & \text { salah } \\
\text { mengatur } & \text { ukuran } \\
\text { doubleend } & \text { sesuai } \\
\text { pesanan } & \\
\end{array}$ & $\begin{array}{l}\text { Produk } \\
\text { doubleend cacat }\end{array}$ & 1 & - & - \\
\hline \multirow[t]{3}{*}{6} & 6.1 .1 & $\mathrm{~A} 4$ & $\begin{array}{l}\text { Operator mengambil } \\
\text { kayu dengan posisi } \\
\text { tubuh yang salah dan } \\
\text { tidak memakai } \\
\text { sarung tangan safety }\end{array}$ & $\begin{array}{l}\text { Produk flooring } \\
\text { terjatuh dan } \\
\text { akan menjadi } \\
\text { cacat produk, } \\
\text { dapat } \\
\text { menyebabkan } \\
\text { sakit punggung }\end{array}$ & 3 & - & - \\
\hline & 6.1 .2 & A1 & $\begin{array}{lr}\text { Pekerja } & \text { terlalu } \\
\text { banyak } & \text { mengangkut } \\
\text { kayu } & \end{array}$ & $\begin{array}{l}\text { Jari tergores, } \\
\text { tangan keseleo }\end{array}$ & 2 & 1 & 2 \\
\hline & 6.1 .3 & $\mathrm{C} 2$ & $\begin{array}{l}\text { Salah mensetting } \\
\text { mesin }\end{array}$ & $\begin{array}{l}\text { Permukaan } \\
\text { produk flooring } \\
\text { kurang rapi }\end{array}$ & 1 & - & - \\
\hline \multirow[t]{4}{*}{7} & 7.1 .1 & $\mathrm{I} 1$ & $\begin{array}{l}\text { Operator mengangkut } \\
\text { tumpukan } \\
\text { terlalu banyak }\end{array}$ & $\begin{array}{l}\text { Tumpukan } \\
\text { kayu jatuh } \\
\text { sehingga }\end{array}$ & & & \\
\hline & & & & $\begin{array}{l}\text { produk kayu } \\
\text { cacat, pekerja } \\
\text { tertimpa } \\
\text { tumpukan kayu }\end{array}$ & 2 & - & - \\
\hline & 7.1 .2 & A5 & $\begin{array}{lr}\text { Oeprator } & \text { forklift } \\
\text { menumpuk } & \text { kayu } \\
\text { terlalu tinggi } & \end{array}$ & $\begin{array}{l}\text { Tumpukan } \\
\text { kayu terjatuh } \\
\text { dari forklift }\end{array}$ & 2 & - & - \\
\hline & 7.2 .1 & A8 & $\begin{array}{l}\text { Pekerja kurang teliti } \\
\text { dalam membersihkan } \\
\text { ruang mesin kilndry }\end{array}$ & $\begin{array}{l}\text { Mata terpapar } \\
\text { debu }\end{array}$ & 1 & - & - \\
\hline
\end{tabular}




\begin{tabular}{|c|c|c|c|c|c|c|c|}
\hline & 7.2 .2 & $\mathrm{C} 1$ & $\begin{array}{l}\text { Salah mengatur ulang } \\
\text { suhu kilndry }\end{array}$ & $\begin{array}{l}\text { Kulit terbakar } \\
\text { atau pekerja } \\
\text { kedinginan }\end{array}$ & 1 & - & - \\
\hline & 7.3 .1 & $\mathrm{C} 1$ & $\begin{array}{l}\text { Lupa melalukan } \\
\text { pengecekkan }\end{array}$ & $\begin{array}{lr}\text { Suhu ruang } \\
\text { mesin kilndry } \\
\text { tidak terkontrol }\end{array}$ & 1 & - & - \\
\hline 8 & 8.1 & $\mathrm{C} 2$ & $\begin{array}{l}\text { Salah mengatur ulang } \\
\text { ketebalan potongan } \\
\text { papan }\end{array}$ & $\begin{array}{lr}\text { Tebal } & \text { papan } \\
\text { tidak } & \text { sesuai } \\
\text { dengan } & \text { pesanan }\end{array}$ & 1 & - & - \\
\hline & 8.2 & C1 & $\begin{array}{l}\text { Tidak melakukan } \\
\text { pengecekkan dengan } \\
\text { teliti }\end{array}$ & $\begin{array}{l}\text { Panjang dan } \\
\text { lebar produk } \\
\text { tidak sama rata }\end{array}$ & 1 & - & - \\
\hline & 8.3 & $\mathrm{C} 1$ & $\begin{array}{l}\text { Melewatkan } \\
\text { pengecekkan rutin }\end{array}$ & $\begin{array}{l}\mathrm{T} \& \mathrm{G} \quad \text { dan } \\
\text { double end } \\
\text { tidak terbentuk } \\
\text { dengan rapi }\end{array}$ & 1 & - & - \\
\hline & 8.4 & $\mathrm{C} 2$ & $\begin{array}{l}\text { Tidak melakukan } \\
\text { kontrol rutin }\end{array}$ & $\begin{array}{l}\text { Permukaan } \\
\text { kurang halus }\end{array}$ & 1 & - & - \\
\hline & 8.5 & C1 & $\begin{array}{l}\text { Salah menentukan } \\
\text { suhu ruang mesin }\end{array}$ & $\begin{array}{l}\text { Kulit terbakar } \\
\text { atau pekerja } \\
\text { kedinginan }\end{array}$ & 1 & - & - \\
\hline & 8.6 & $\mathrm{C} 2$ & $\begin{array}{l}\text { Pekerja melakukan } \\
\text { pengepackan secara } \\
\text { asal-asalan }\end{array}$ & $\begin{array}{l}\text { Pengepackan } \\
\text { kurang rapi }\end{array}$ & 1 & - & - \\
\hline 9 & 9.1 & A1 & $\begin{array}{lr}\text { Pekerja } & \text { ceroboh } \\
\text { dalam } & \text { mengangkut } \\
\text { kardus } & \end{array}$ & Sakit punggung & 0 & - & - \\
\hline & 9.2 & $\mathrm{~S} 2$ & $\begin{array}{lr}\text { Salah } & \text { dalam } \\
\text { menyusun } & \text { saat } \\
\text { pengepackan } & \end{array}$ & $\begin{array}{l}\text { Pengepackan } \\
\text { tidak rapi, kaki } \\
\text { tertimpa } \\
\text { tumpukan } \\
\text { produk }\end{array}$ & 1 & - & - \\
\hline & 9.3 & A3 & $\begin{array}{l}\text { Ikatan tidak rapi dan } \\
\text { tidak kuat }\end{array}$ & $\begin{array}{l}\text { Bisa } \\
\text { menyebabkan } \\
\text { kerusakan } \\
\text { produk flooring }\end{array}$ & 1 & - & - \\
\hline
\end{tabular}

Tabel 2, tabel 3, tabel 4, dan tabel 5 merupakan pengolahan data dengan metode SHERPA. Kegiatan dikelompokkan dalam tabel mode error, kemudian mendeskripsikan error yang terjadi dan mengidentifikasi konsekuensi yang ditimbulkan dari error tersebut, tahap terakhir yaitu melakukan wawancara kepada narasumber untuk mengetahui tingkat keparahan dari error yang terjadi. Konsekuensi error meliputi aspek produk dan operator.

\subsection{JSA}

Tabel 6 merupakan rekapitulasi jenis error terbesar dan dapat dililihat bahwa mengambil potongan papan setelah dipotong menggunakan mesin band saw, memotong papan menggunakan mesin band resaw dan memotong kayu dengan mesin cross cut memiliki Nilai Skor Resiko masing-masing 15, 20 dan 15. 
Tabel 6 Rekapitulasi Jenis Error Terbesar

\begin{tabular}{llccc}
\hline \multicolumn{1}{c}{ Proses } & \multicolumn{1}{c}{ Jenis Error } & $\begin{array}{c}\text { Skor } \\
\text { Resiko }\end{array}$ & $\begin{array}{c}\text { Mode } \\
\text { Error }\end{array}$ & $\begin{array}{c}\text { Analisis } \\
\text { Probabilitas } \\
\text { Human Error }\end{array}$ \\
\hline $\begin{array}{l}\text { Penggergajian } \\
\text { Balok }\end{array}$ & $\begin{array}{l}\text { Mengambil potongan papan setelah } \\
\text { dipotong menggunakan mesin } \\
\text { bandsaw }\end{array}$ & 15 & $\mathrm{~A} 8$ & $\mathrm{H}$ \\
$\begin{array}{l}\text { Pemotongan } \\
\text { Lebar Kayu }\end{array}$ & $\begin{array}{l}\text { Memotong papan menggunakanm } \\
\text { mesin bandresaw }\end{array}$ & 20 & $\mathrm{~A} 7$ & $\mathrm{H}$ \\
Panjang Kayu & $\begin{array}{l}\text { Memotong kayu dengan mesin } \\
\text { crosscut }\end{array}$ & 15 & $\mathrm{~A} 7$ & $\mathrm{H}$ \\
\hline
\end{tabular}

\subsection{Rekomendasi Perbaikan yang diusulkan}

\section{Penggergajian Balok}

Melakukan persiapan kerja sebelum pekerjaan dimulai dan evaluasi setelah pekerjaan selesai. Persiapan pekerja mulai dari kelengkapan pakaian (APD) seperti sarung tangan safety, kacamata safety, masker safety, earplug, coverall, sepatu safety, dan evaluasi setelah menyelesaikan pekerjaan meliputi kendala yang dialami pada hari itu.

2. Pemotongan Lebar Kayu

a. Melakukan briefing kepada operator dibagian pemotongan lebar kayu agar lebih berhati-hati melakukan pekerjaan. Briefing meliputi menjaga kesehatan dan keselamatan ditempat kerja dan posisi tubuh saat bekerja. Pekerja akan dilatih posisi tubuh yang benar saat melakukan pemotongan dan mengangkat kayu. Menambah alat bantu berupa pembatas mesin dengan operator.

b. Membuat desain pembatas antara mesin band resaw dengan operator :

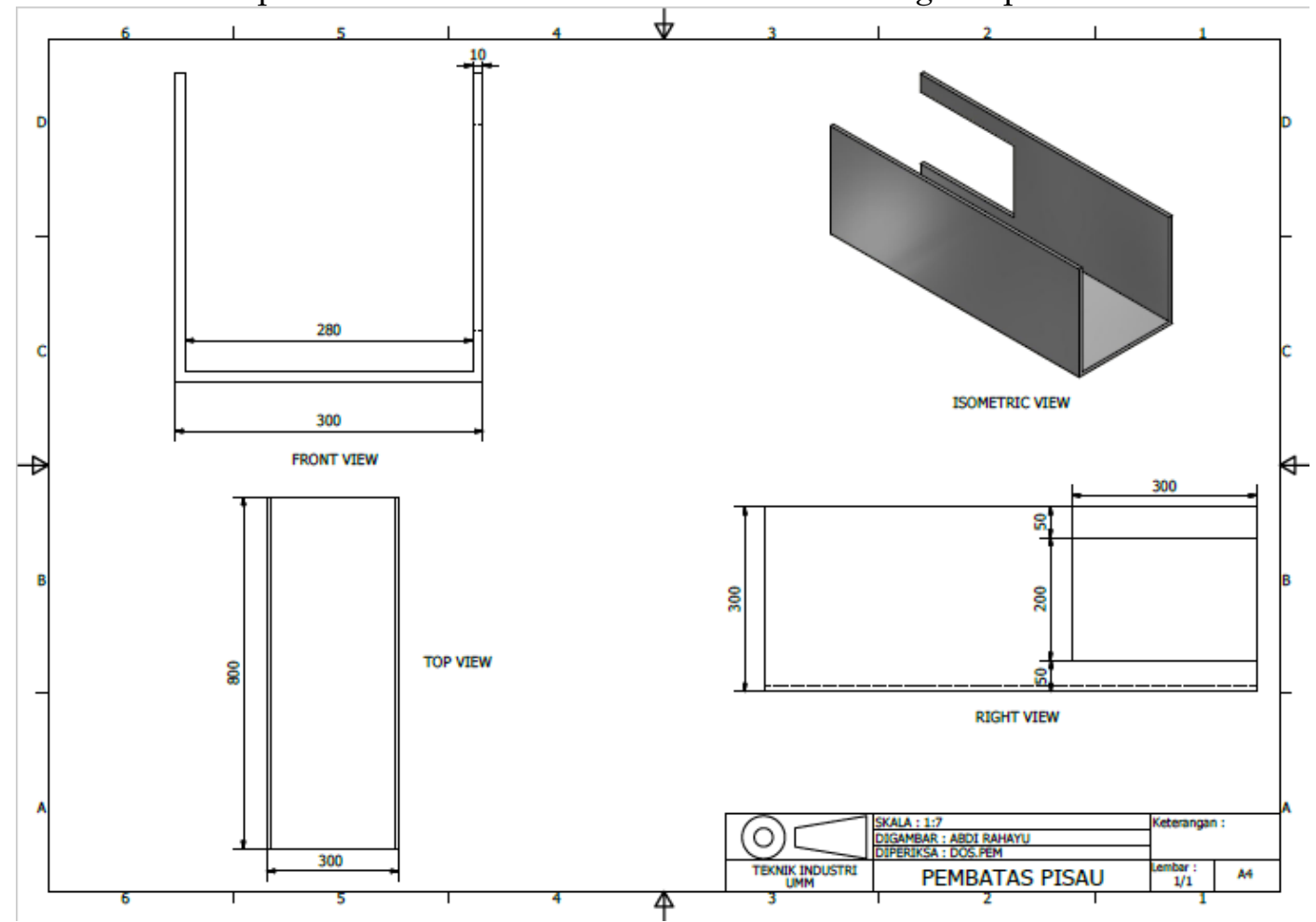

Gambar 2 Desain Pembatas Mesin 


\section{Pemotongan Panjang Kayu}

a. Melakukan pelatihan pada bagian pemotongan panjang kayu agar operator lebih berhati-hati dalam melakukan pekerjaan.

b. Membuat desain handle pemegang kayu pada mesin crosscut :

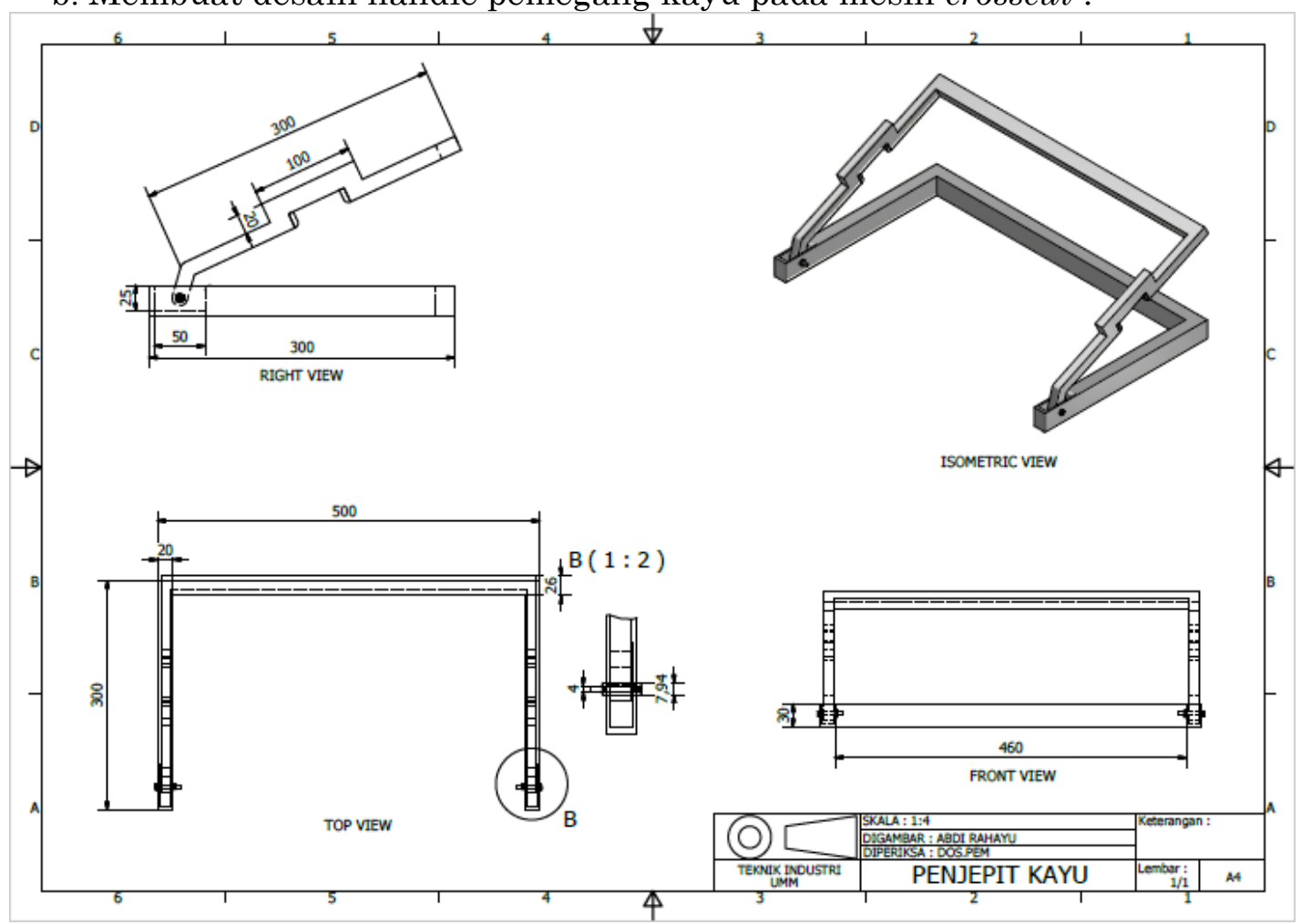

Gambar 3 Desain Handle Pemegang Kayu

\section{Simpulan}

Dari pengolahan data hasil makalah di Perum Perhutani KBM Industri Kayu Gresik dan penyelesaian dengan metode SHERPA (Systematic Human Error Reduction and Prediction) maka dapat diketahui bahwa kecelakaan kerja di Perum Perhutani disebabkan oleh operator tidak memakai APD berupa sarung tangan safety, kacamata safety, earplug, sepatu safety dan tidak dilakukannya training secara berkala pada stasiun penggergajin balok. Tidak ada pembatas antara tangan operator dengan pisau mesin bandresaw, operator tidak memakai APD berupa sarung tangan safety, kacamata safety dan earplug. Tidak adanya handle yang berguna sebagai pemegang kayu, operator tidak menggunakan APD berupa masker, sarung tangan safety, kacamata safety dan coverall. Metode JSA memberikan analisa perbaikan pada kecelakaan yang terjadi pada proses produksi flooring. Berdasarkan dari Penilaian Skor Resiko pada metode SHERPA diperoleh 3 kegiatan berbahaya yaitu kegiatan nomor 1.4, 2.4 dan 3.3. kegiatan tersebut dianalisis dan diberikan usulan perbaikan masing-masing, melakukan training secara rutin, desian pelindung, desain pemegang (handle) operator dan penggunaan APD lengkap yang telah berstandar safety untuk operator diseluruh lantai produksi terutama lantai produksi flooring. Hasil dari analisis JSA yaitu berupa form JSA sebagai pedoman perusahaan untuk melakukan perbaikan pada pekerjaan yang berbahaya. 


\section{Referensi}

[1] W. Findiastuti, S. Wignjosoebroto, and D. S. Dewi, "Analisa Human Error Dalam Kasus Kecelakaan Di Persilangan Kereta Api," 2000.

[2] T. Rahmania, E. Ginting, and B. M. Kes, "Analisa Human Error Dengan Metode Sherpa Dan Heart Pada Kecelakaan Kerja Di Pt "Xyz"," Jurnal Teknik Industri USU, vol. 2, 2013.

[3] N. A. Stanton, P. Salmon, and G. Walker, "Human factors design methods review," 2003.

[4] A. Hutama, "Analisa Kecelakaan Kerja Menggunakan Metode Heart (Human Error Assessment And Reduction Technique) Dan Jsa (Job Safety Analysis) (Perusahaan Raket Abadi Malang)," University of Muhammadiyah Malang, 2015.

[5] C. M. Hughes, C. Baber, M. Bienkiewicz, A. Worthington, A. Hazell, and J. Hermsdörfer, "The application of SHERPA (Systematic Human Error Reduction and Prediction Approach) in the development of compensatory cognitive rehabilitation strategies for stroke patients with left and right brain damage," Ergonomics, vol. 58, pp. 75-95, 2015.

[6] S. Mandal, K. Singh, R. Behera, S. Sahu, N. Raj, and J. Maiti, "Human error identification and risk prioritization in overhead crane operations using HTA, SHERPA and fuzzy VIKOR method," Expert Systems with Applications, vol. 42, pp. 7195-7206, 2015.

[7] Y. Rasoulzadeh, S. S. Alizadeh, S. Valizadeh, H. Fakharian, and S. Varmazyar, "Health, safety and ergonomically risk assessment of mechanicians using Job Safety Analysis (JSA) technique in an Iran City," Indian Journal of Science and Technology, vol. 8, 2015. 